\title{
STRATEGI REVITALISASI PERPUSTAKAAN KAMPUS DALAM MENCIPTAKAN BUDAYA LITERASI
}

\author{
Tri Winda Astuti \\ Pustakawan IAIN Bengkulu \\ triwindajoni@gmail.com
}

\begin{abstract}
Abstrak:
Revitalisasi perpustakaan merupakan usaha yang dilakukan agar perpustakaan dapat memegang perannya kembali sebagaimana mestinya. Tujuan dari program ini adalah untuk mewujudkan perpustakaan kampus dalam menciptakana budaya literasi melalui kegiatan pembaharuan pengelolaan perpustakaan, sehingga perpustakaan kembali berperan sebagai jantung pendidikan. Dalam pelaksanaannya, program revitalisasi perpustakaan dilakukan dengan strategi yang terdiri dari 3 aspek yaitu administrasi, fisik, dan sumber daya manusia (SDM). Selanjutnya setiap kampus diharapkan dapat mengembangkan ketiga aspek tersebut melalui kegiatan yang yang bervariasi.
\end{abstract}

Kata Kunci: Strategi, Revitalisasi Perpustakaan

\begin{abstract}
:
Library revitalization is an effort made so that libraries can play their role again as they should. The purpose of this program is to create a campus library in creating a culture of literacy through library management renewal activities, so that the library again plays a role as the heart of education. In its implementation, the library revitalization program is carried out with a strategy consisting of 3 aspects, namely administration, physicality, and human resources (HR). Furthermore, each campus is expected to be able to develop these three aspects through various activities.
\end{abstract}

Keywords: Strategy, Library Revitalization

\section{Pendahuluan}

Literasi biasanya dipahami sebagai kemampuan membaca dan menulis. Pengertian tersebut berkembang menjadi konsep literasi fungsional, yaitu literasi yang berkaitan dengan berbagai fungsi dan keterampilan hidup. ${ }^{1}$ Menurut UNESCO literasi merupakan seperangkat keterampilan nyata, khususnya keterampilan kognitif membaca dan menulis yang terlepas dari konteks dimana keterampilan itu diperoleh dan dari siapa memperolehnya. UNESCO menjelaskan bahwa kemam

\footnotetext{
${ }^{1}$ Pakistyaningsih, Arini, dkk, Menuju Wujud Surabaya Sebagai Kota Literasi, (Surabaya: Pelita Hati, 2014).
}

puan literasi merupakan hak setiap orang dan merupakan dasar untuk belajar sepanjang hayat.

Selain itu, di dalam ajaran agama Islam sendiri terdapat perintah yang bermakna literasi melalui wahyu pertama yakni surat Al-Alaq ayat 1 yang berbunyi "Iqra" yang artinya bacalah. Hal tersebut menunjukkan bahwa literasi memang sangat penting, sebagaimana yang dijelaskan oleh UNESCO bahwa dengan kemampuan literasi akan dapat membantu memberantas kemiskinan, mengurangi angka kematian anak, pertumbuhan penduduk, dan menjamin pembangunan berkelanjutan, dan terwujudnya perdamaian. 
Tri Winda Astuti

Strategi Revitalisasi Perpustakaan Kampus

Dalam Menciptakan Budaya Literasi

Menurut Dharma bahwasanya Indonesia merupakan salah satu negara yang kemampuan literasinya tertinggal. Fakta menyedihkan tersebut didukung dengan beberapa penelitian. Salah satunya hasil studi menunjukkan bahwa kemampuan membaca dan apresiasi masyarakat Indonesia terhadap kegiatan membaca masih sangat rendah $^{2}$. Lebih lanjut menurut Pakistyaningsih, bahwa hasil tes ujian PISA menempatkan siswa Indonesia pada posisi kedua terburuk atau posisi 64 dari 65 negara. ${ }^{3}$

Rendahnya reading literacy bangsa kita saat ini dan di masa depan akan membuat rendahnya daya saing bangsa dalam persaingan global. Hal ini sebenamya sudah bisa kita lihat dengan nyata. Saat ini Tenaga Kerja Indonesia (TKI) berjumlah 6,5 juta orang dan tersebar di 142 negara. Para TKI ini hanya mengisi posisi sebagai tenaga kasar yang tidak membutuhkan kemampuan membaca. ${ }^{4}$ Hal tersebut sudah menunjukkan bahwa tanpa kemampuan literasi yang baik dalam persaingan global ini maka TKI hanya akan dapat mengisi pekerjaan-pekerjaan kasar dengan gaji paling rendah. Tanpa upaya untuk meningkatkan kemampuan membaca sebagai dasar untuk belajar dan mengembangkan keterampilan hidup maka bangsa kita akan terus menjadi bangsa kuli seperti yang disinyalir oleh Soekarno.

\footnotetext{
${ }^{2}$ Dharma, Satria, Transformasi Surabaya sebagai Kota Literasi, (Surabaya: Unesa University Press, 2016).

${ }^{3}$ Pakistyaningsih, Arini, dkk, Menuju Wujud Surabaya Sebagai Kota Literasi, (Surabaya:Pelita Hati, 2014)

${ }^{4}$ Pakistyaningsih, Arini, dkk, Menuju Wujud Surabaya Sebagai Kota Literasi, (Surabaya:Pelita Hati, 2014)
}

Dengan demikian kemajuan teknologi yang sangat pesat ini belum diimbangi dengan adanya budaya literasi. Semakin sering seseorang suka membaca maka akan membawa pengaruh positif dalam pembentukan karakternya. Dengan membaca, seseorang terutama anak-anak akan terlatih imajinasinya sehingga mereka bisa berpikir lebih kreatif.

Dalam rangka melakukan revitalisasi perpustakaan di kampus menuju budaya literasi merupakan suatu terobosan yang positif untuk meningkatkan budaya membaca dan menulis yang tinggi bagi mahasiswa. Revitalisasi perpustakaan merupakan usaha yang dilakukan agar perpustakaan dapat memegang perannya kembali sebagaimana mestinya. Tujuan dari program ini adalah untuk mewujudkan kampus menuju budaya literasi melalui kegiatan pembaharuan pengelolaan perpustakaan kampus, sehingga perpustakaan kampus kembali berperan sebagai jantung ilmu pengetahuan.

\section{Tinjauan Pustaka}

\section{Revitalisasi Perpustakaan}

Menurut Kamus Besar Bahasa Indonesia revitalisasi berasal dari kata "vital" yang berarti "sangat penting". Penambahan kata "re" sebelum kata "vital" dapat bermakna proses pengulangan atau sikap sadar untuk melakukan upaya atau usaha. Jadi kata "revitalisasi" itu berarti upaya untuk melakukan perbaikan (pementingan) dari beberapa kekurangan yang ada dan 
diketahui sebelumnya. ${ }^{5}$ Sedangkan menurut perpustakaan adalah suatu unit kerja dari suatu badan atau lembaga tertentu yang mengelola bahan- bahan pustaka, baik berupa buku-buku maupun bukan berupa buku (non book materia) yang diatur secara otomatis menurut aturan tertentu sehingga dapat digunakan sebagai sumber informasi oleh setiap pemakainya. 6

Dalam buku pedoman penyelenggaraan perpustakaan sekolah, perpustakaan mempunyai arti sebagai suatu tempat yang di dalamnya terdapat kegiatan penghimpunan, pengolahan, dan penyebarluasan (pelayanan) segala macam informasi, baik yang tercetak maupun yang terekam dalam berbagai media seperti buku, majalah, surat kabar, film, kaset, tape recorder, video, komputer dan lain-lain. ${ }^{7}$

Dalam hal ini, perpustakaan yang dimaksud adalah perpustakaan kampus. Tujuan perpustakaan kampus adalah untuk menunjang pelaksanaan program pendidikan, yang antara lain dikemukakan oleh Shaleh, sebagai berikut.

1. Untuk menimbulkan, menanamkan serta membina minat anak membaca, sehingga membaca merupakan suatu kebiasaan bagi mahasiswa agar membaca menjadi kegemarannya.

\footnotetext{
5 Tim Penyusun Kamus Pusat Bahasa, Kamus Besar Bahasa Indonesia, (Jakarta: Balai Pustaka, 2002)

${ }^{6}$ Bafadal, Ibrahim, Pengelolaan Perpustakaan Sekolah, (Jakarta: Bumi Aksara, 2006).

${ }^{7}$ Prawit, M. Yusuf, Pedoman Penyelenggaraan Perpustakaan Sekolah, (Jakarta: Kencana, 2005).
}

2. Untuk memperluas horison pengetahuan mahasiswa, dengan menyediakan berbagai buku-buku pengetahuan.

3. Ikut membantu perkembangan bahasa dan daya pikir mahaiswa, dan untuk memberikan dorongan kepada mahasiswa ke arah self study.

Sebagai bangunan suatu teori tertentu, menurut Mustofa maka untuk merevitalisasi memiliki beberapa prinsip yang harus dipakai, diantaranya:

1. Objek revitalisasi (tempat atau masalah yang akan diberdayakan) jauh dalam rentang waktu sebelumnya sudah pernah menjadi vital (sudah pernah terberdaya).

2. Disaat akan melakukan revitalisasi, tempat atau masalah yang menjadi objek dimaksud dalam kondisi menurun atau kurang terberdaya lagi.

3. Target dilakukannya revitalisasi adalah untuk memulihkan kembali kondisi suatu tempat atau masalah, minimal sama dengan vitalitas yang pernah digapai sebelumnya, tambah bagus lebih baik lagi. ${ }^{9}$

Dengan demikian revitalisasi perpustakaan merupakan usaha yang dilakukan agar perpustakaan dapat memegang perannya kembali sebagaimana mestinya. Tujuan dari program ini adalah untuk mewujudkan kampus belajar

\footnotetext{
${ }^{8}$ Ibnu, Ahmad Shaleh, Penyelenggaraan Perpustakaan Sekolah, (Jakarta: PT. Hidayah Agung, 1999).

9 Mustofa, Ahmad, "Revitalisasi Pendidikan Pesantren”, Surabaya, 20 Juli, 2009, diakses 01Desember2017,revitalisasipendidikanpesantren.blogspot. co.id/2009/07/bab-ii-revitalisasipendidikan. html
} 
Tri Winda Astuti

Strategi Revitalisasi Perpustakaan Kampus Dalam Menciptakan Budaya Literasi

menuju budaya literasi melalui kegiatan pembaharuan pengelolaan perpustakaan kampus, sehingga perpustakaan kampus kembali berperan sebagai jantung ilmu pengetahuan.

\section{Strategi Pengelolaan Revitalisasi Per- pustakaan Kampus Menuju Budaya Lit- erasi}

Strategi merupakan sarana yang digunakan untuk mencapai tujuan akhir dari suatu organisasi, namun strategi bukanlah sekedar suatu rencana, melainkan adalah rencana yang menyatukan. Strategi juga merupakan aspek terpenting dalam suatu organisasi. Oleh karena itu penentuan strategi membutuhkan tingkatan komitmen dan tanggungjawab dari suatu organisasi dalam memajukan strategi yang mengacu pada hasil atau tujuan akhir. $^{10}$

Dalam pengelolaan revitalisasi perpustakaan merupakan salah satu program yang di ciptakan sebagai strategi normatif edukatif di dalam pengelolaannya. Melalui revatalisasi perpustakaan ini beberapa kegiatan yang dilakukan antara lain meliputi revitalisasi fisik, revitalisasi administrasi, dan revitalisasi Sumber Daya Manusia. Beberapa kegiatan tersebut dapat dijabarkan sebagai berikut:

1. Revitalisasi Fisik

Hartono menjelaskan bahwa sarana dan prasarana kampus yang berperan sebagai salah satu pusat sumber belajar di-

\footnotetext{
${ }^{10}$ Sutarno, NS, Manajemen Perpustakaan: Suatu Pendekatan Praktik (Jakarta: Samitra Media Utama, 2004).
}

perlukan sebagai tempat melakukan kegiatan secara fisik dalam penyelenggaraan perpustakaan. $^{11}$ Fisik dapat diartikan sebagai jasmani, raga, badan, materi, benda riil, perangkat keras, dan sesuatu yang berkaitan dengan alam. Jadi revitalisasi fisik adalah mengaktifkan kembali, memvitalkan kembali atau meremajakan kembali sarana dan prasarana perpustakaan.

Dalam pelaksanaannya, revitalisasi ini berfokus kepada pembaharuan kondisi fisik perpustakaan, mulai dari perbaikan buku-buku yang rusak, penataan buku-buku di dalam rak, hiasan/pajangan di dalam ruangan, keindahan dan kebersihan perpustakaan, dan lain sebagainya.

Hal tersebut dilakukan agar para mahasiswa merasa nyaman dan betah pada saat berkunjung ke perpustakaan. Kegiatan revitalisasi fisik dilaksanakan berdasarkan standar $\mathrm{Na}$ sional perpustakaan sebagai acuannya. Diantaranya sebagai berikut:

a. Gedung / ruang perpustakaan

Gedung perpustakaan merupakan bangunan yang sepenuhnya dipergunakan untuk kegiatan perpustakaan dan berdiri sendiri. Ruang perpustakaan adalah bagian dari sebuah gedung yang digunakan untuk beberapa kegiatan perpustakaan. Menurut Hartono, berikut merupakan standar $\mathrm{Na}$ -

\footnotetext{
${ }^{11}$ Hartono, Dasar-dasar Manajemen Perpustakaan dari Masa ke Masa (Malang: UIN Maliki Press, 2015).
} 
Almaktabah Vol. 5, No. 2, Desember 2020

sional ruang perpustakaan standar Nasional ruang perpustakaan:

1) Ruang koleksi

Ruang koleksi adalah ruangan yang digunakan untuk memajang bahan pustaka yang baru dan menyimpan yang lama.

2) Ruang baca

Ruang baca adalah ruangan yang digunakan untuk membaca dan belajar yang dilengkapi dengan meja belajar (study carre).

3) Ruang staf

Pada ruang staf ini terdiri dari ruang layanan dan ruang pengolahan. Ruang layanan adalah ruang perpustakaan yang digunakan untuk melayani peminjaman buku, menyimpan bahan rujukan, kartu katalog dan tempat kerja petugas, serta untuk memajang bukubuku baru. Sedangkan ruang pengolahan adalah ruang yang digunakan untuk aktivitas pengadaan dan pengolahan bahan pustaka.

4) Ruang Lain-Lain

Ruang ini merupakan ruang tambahan pendukung kegiatan perpustakaan.

b. Perabot dan peralatan perpustakaan

Perabot dan perlengkapan perpustakaan kampus yang baik tidak hanya memiliki estetika dan daya tahan lama atau kokoh, tetapi juga berdaya guna tinggi (fungsional). ${ }^{12}$

2. Revitalisasi Administrasi

Menurut Tantriana bahwa administrasi berasal dari bahasa latin administrate, ad berari intensif sedangkan administrate berarti melayani, membantu, dan memenuhi, jadi tugas utama seorang administrator adalah memberikan layanan prima. Istilah administrasi dibagi menjadi 2, yaitu pengertian sempit dan pengertian luas. Adapun administrasi dalam pengertian sempit adalah suatu pekerjaan tata usaha dalam kantor. Sedangkan administrasi dalam pengertian luas adalah seluruh prooses kerjasama antara dua orang atau lebih dalam mencapai tujuan bersama. Dari beberapa pengertian dapat diartikan bahwa administrasi adalah sekumpulan kegiatan tata usaha atau tata laksana pada sebuah orgnisasi/perusahaan guna menyelesaikan kearsipan yang dianggap kurang sehingga ada nilai tambah guna mempermudah kegiatan tersebut. ${ }^{13}$ Jadi revitalisasi administrasi adalah mengaktifkan kembali, memvitalkan kembali atau meremajakan kembali proses tata usaha dalam pengelolaan perpustakaan.

Dalam pelaksanaannya, kegiatan ini melakukan pembenahan pada sistem administrasi perpustakaan yang meliputi per-

\footnotetext{
12 Hartono, Dasar-dasar Manajemen Perpustakaan dari Masa ke Masa (Malang: UIN Maliki Press, 2015)

${ }^{13}$ Tantriana, Deasy, Teori Administrasi, (Surabaya: UIN Sunan Ampel Press, 2014).
} 
Tri Winda Astuti

Strategi Revitalisasi Perpustakaan Kampus Dalam Menciptakan Budaya Literasi

lengkapan buku, catatan-catatan lain yang dapat mempermudah dalam pengelolaan koleksi perpustakaan, dan sirkulasi pengelolaan buku. Dengan melaksanakan revitalisasi ini, proses administrasi dapat berjalan secara efektif dan efisien, serta meminimalisir kerusakan dan kehilangan koleksi yang dimiliki.

Revitalisasi administrasi dilaksanakan sesuai standar Nasional perpustakaan, diantaranya adalah:

a. Inventaris, yaitu kegiatan memeriksa, memberi stempel, dan mencatat atau mendaftar semua koleksi perpustakaan dalam buku induk.

b. Katalogisasi, yaitu kegiatan membuat entri dalam kartu atau daftar mengenai buku dan bahan pustaka lainnya yang disusun berdasarkan aturan tertentu. Katalogisasi diawali dengan kegiatan pengatalogan deskriptif yaitu menentukan tajuk entri utama dan tajuk entri tambahan, kemudian membuat kartu katalog yang digandakan sesuai kebutuhan (pengarang, judul, subjek, dan jejakan lain), serta shelflist dan dijajarkan pada laci-laci katalog.

c. Klasifikasi, yaitu kegiatan menganalisa isi bahan pustaka dan menetapkan kode menurut sistem tertentu untuk bu$\mathrm{ku}$, karangan dalam majalah, dan lainlain.

d. Penyelesaian, yaitu kegiatan pembuatan dan pemasangan kelengkapan fisik bahan pustaka seperti kantong buku, kartu buku, lembar tanggal kembali, dan label atau tanda buku (nomor panggilan).

e. Layanan sirkulasi, dikenal juga dengan layanan peminjaman. Tujuan layanan ini adalah memperlancar dan mempermudah proses peminjaman koleksi untuk dibawa pulang. Dalam hal ini menurut Hartono, layanan sirkulasi meliputi:

1) Pendaftaran peminjaman

2) Prosedur peminjaman

3) Pemungutan denda

4) Pengawasan buku-buku tendon

5) Waktu peminjaman

6) Statistic peminjaman

7) Pinjam antar perpustakaan ${ }^{14}$

3. Revitalisasi Sumber Daya Manusia (SDM)

Sumber daya manusia pada perpustakaan merupakan salah satu komponen yang sangat penting. Pengembangan sumber daya manusia harus dilakukan dengan baik agar perpustakaan memiliki SDM yang berkualitas. Jadi revitalisasi sumber daya manusia adalah mengaktifkan kembali, memvitalkan kembali atau memfungsikan kembali tenaga perpustakaan.

Secara umum sumber daya manusia pengelola perpustakaan harus mempunyai

\footnotetext{
${ }^{14}$ Hartono, Dasar-dasar Manajemen Perpustakaan dari Masa ke Masa (Malang: UIN Maliki Press, 2015)
} 
minat di bidang kerja perpustakaan, kepedulian yang tinggi terhadap perpustakaan, kemampuan pendekatan pribadi yang baik, kemampuan dibidang teknologi informasi, inisiatif dan kreatifitas, kepekaan terhadap perkembangan-perkembangan yang baru terutama pada bidang perpustakaan serta berdedikasi. ${ }^{15}$

Salah satu komponen penting dan unsur utama perkembangan perpustakaan di tentukan oleh kualitas Sumber Daya Manusia, dengan memberi pengetahuan :

a) Manajemen Perpustakaan kampus

b) Pengolahan bahan Pustaka secara sederhana

c) Layanan, Promosi dan Kerjasama

d) Kemampuan Bercerita.

Terkait dengan program revitalisasi perpustakaan kampus menuju budaya literasi perlu juga didukung berbagai elemen kampus guna mewujudkan budaya literasi bisa tercapai, seperti melakukan berbagai kegiatan, diantaranya;

1. Reading together, adalah kegiatan membaca bersama yang dilakukan setiap 3 bulan sekali.

2. Meresume buku, kegiatan ini merupakan kegiatan lanjutan dari Reading together. Jadi setelah membaca, mahasiswa diharuskan untuk meresume buku yang dibaca.

3. Membaca 15 menit, kegiatan ini berdasarkan himbauan dari Kementrian Pendidikan dan Kebudayaan.

${ }^{15}$ Hartono, Dasar-dasar Manajemen Perpustakaan dari Masa ke Masa (Malang: UIN Maliki Press, 2015)
4. Donor buku, kegiatan infaq atau jariyah buku ini dilaksanakan setiap satu tahun sekali. Dengan adanya kegiatan tersebut dapat menambah koleksi buku di perpustakaan kampus sehingga dapat meningkatkan minat baca mahasiswa karena bahan bacaan bervariasi.

Dari berbagai kegiatan tersebut diharapkan budaya literasi di kampus dapat terwujud sehingga dapat menjadi mahasiswa memiliki budaya membaca dan menulis yang tinggi dan dapat bersaing dengan mahasiswa-mahasiswa dari kampus yang lain.

\section{Metode Penelitian}

Adapun penelitian ini, mengunakan penelitian studi kepustakaan (library research). Jenis penelitan kepustakaan (library research) merupakan penelitian yang berkenaan dengan metode pengumpulan data pustaka yang objek penelitiannya digali melalui beragam informasi kepustakaan (buku, jurnal ilmiah dan hasil penelitian). $^{16}$ Teknik pengumpulan data yang digunakan dalam penelitian ini adalah studi dokumentasi. Data yang digunakan pada penelitian ini adalah data sekunder (data yang diperoleh dari hasil penelitian terdahulu). Sumber data tersebut berupa buku dan jurnal ilmiah yang berkenaan dengan tujuan penelitian. Analisis data dilaksanakan dengan teknik analisis deskriptif dan analisis konten (content analysis) untuk dapat menjelaskan kontribusi publikasi ilmiah bagi pustakawan dan strategi pengem-

\footnotetext{
${ }^{16}$ Sukmadinata, Nana Syaodih. Metode Penelitian Pendidikan (Bandung: Remaja Rosdakarya, 2009)
} 
Tri Winda Astuti

Strategi Revitalisasi Perpustakaan Kampus

Dalam Menciptakan Budaya Literasi

bangan kompetensi pustakawan dalam menghasilkan publikasi ilmiah.

\section{Hasil dan Pembahasan}

Strategi revitalisasi perpustakaan merupakan kegiatan pembaharuan pengelolaan perpustakaan dalam mewujudkan budaya literasi. Hal itu sesuai dengan pernyataan Gouillart dan Kelly bahwa revitalisasi merupakan suatu perubahan yang ditujukan untuk memacu pertumbuhan organisasi atau lembaga dengan cara menselaraskan sesuai lingkungannya (Santoso, 2009: 19). ${ }^{17}$

Dalam hal ini revitalisasi perpustakaan merupakan salah satu bentuk dari normatif edukatif strategy yang dilaksanakan pada lembaga Pendidikan. Menurut Hunger dan Wheelen tahapan dalam proses strategi. Diantaranya adalah analisis lingkungan, perumusan strategi, pelaksanaan strategi, dan evaluasi dan pengendalian. $^{18}$

Pertama tahap analisis lingkungan. Lingkungan internal terdiri dari variabel-variabel (kekuatan dan kelemahan) yang ada di dalam organisasi itu sendiri. Variabel-variabel ini meliputi struktur, budaya, dan sumber daya organisasi. 1) struktur ialah cara penyusunan organisasi dalam arti komunikasi, otoritas, dan aliran kerja. 2) Budaya ialah pola keyakinan dan nilainilai para anggota organisasi yang biasanya

\footnotetext{
${ }^{17}$ Santoso, Wulandoro, Revitalisasi Dewan Pendidikan, Jurnal Ilmu Pendidikan, no.4 (juni:2009)

${ }^{18}$ Kholis, Nur. Manajemen Strategi Pendidikan (Surabaya: UIN Sunan Ampel Press, 2014)
}

secara tipikal muncul dan menentukan perilaku anggota yang dapat diterima mulai dari manajemen puncak sampai karyawan pelaksana. 3) Sumber daya organisasi adalah aset yang merupakan bahan- bahan mentah bagi produk organisasi baik barang ataupun jasa. Aset ini meliputi keterampilan manusia, kepandaian, dan bakat- bakat manajerial, maupun aset finansial dan fasilitas-fasilitas yang ditanamkan di dalam area fungsional.

Kedua tahap perumusan strategi strategi ialah pengembangan rencana jangka panjang untuk pengelolaan secara efektif peluang dan ancaman lingkungan. a) Misi, adalah maksud dan tujuan atau alasan keberadaan organisasi. b) Sasaran, ialah hasil-hasil akhir dari aktivitas yang direncanakan. Sasaran menyatakan tentang apa yang harus dicapai dengan cara bagaimana dan kapan. Istilah sasaran berbeda dengan tujuan, dalam hal ini tujuan sendiri merupakan suatu pernyataan open-ended tentang apa yang orang inginkan untuk dicapai dan tanpa jangka waktu kapan mencapainya. c) Strategi,merupakan rencana komprehensif yang menyatakan bagaimana organisasi ingin mencapai misi dan sasarannya. Strategi memaksimumkan keunggulan kompetitif dan meminimumkan kelemahan kompetitif. d) Kebijakan, pedoman luas bagi bagian-bagian untuk diikuti sesuai dengan strategi organisasi. Kebijakan memberikan pedoman yang luas untuk pembuatan keputusan dalam organisasi. 
Ketiga tahap pelaksanaan strategi adalah proses menterjemahkan strategi dan kebijakan menjadi aksi melalui pengembangan program, anggaran biaya, dan prosedur pelaksanaan. a) Program, adalah pernyataan tentang aktivitas atau langkah-langkah yang diperlukan untuk mencapai hanya satu rencana yang dipergunakan, yang menjadi strategi dan berorientasi pada aksi. b) Anggaran biaya, adalah pernyataan tentang program-program organisasi menurut perhitungan rupiah/dolar, pembuatan daftar secara rinci biaya tiap-tiap program yang digunakan oleh manajemen baik dalam perencanaan dan pelaksanaan maupun pengendalian. c) prosedur, adalah sistem tentang langkah-langkah sekuensial atau teknik-teknik yang menguraikan secara rinci bagaimana suatu tugas atau pekerjaan tertentu harus dilakukan.

Keempat tahap evaluasi dan pengendalian. Evaluasi dan pengendalian adalah proses pemantauan dan penilaian aktivitas kinerja organisasi aktualnya dibandingkan dengan kinerja yang diinginkan. Agar evaluasi dan pengendalian itu efektif, maka manajer harus segera memperoleh umpan balik yang jelas dan tidak bias dari orang-orang bawahannya di dalam organisasi secara hirarkis.

\section{Kesimpulan}

Strategi pengelolaan perpustakaan kampus dalam menciptakan budaya literasi perlu mendapat dukungan dari berbagai pihak terutama para petinggi kampus, sehingga dalam menerapkan normatif edukatif strategy yang digunakan dalam pengelolaan revitalisasi perpustakaan dalam menciptakan budaya literasi dapat dilakukan dengan program sudut baca, 15 menit membaca, reading together dan meresume, donor buku, tantangan membaca dan revitalisasi perpustakaan.

Dengan demikian sebenarnya kampus tetap bisa melaksanakan kegiatan literasi maupun pengelolaan perpustakaan dengan baik. Tergantung bagaimana manajemen yang di terapkan oleh kampus tersebut. Sehingga kegiatan tetap dapat berjalan sesuai dengan rencana yang telah ditentukan.

\section{Daftar Pustaka}

Bafadal, Ibrahim. (2006). Pengelolaan Perpustakaan Sekolah, Jakarta: Bumi Aksara.

Dharma, Satria, 2016. Transformasi Surabaya sebagai Kota Literasi, Surabaya: Unesa University Press.

Hartono. (2015). Dasar-dasar Manajemen Perpustakaan dari Masa ke Masa. Malang: UIN Maliki Press.

Ibnu, Ahmad Shaleh. (1999). Penyelenggaraan Perpustakaan Sekolah, Jakarta: PT. Hidayah Agung.

Kholis, Nur. (2014). Manajemen Strategi Pendidikan, Surabaya: UIN Sunan Ampel Press.

Mustofa, Ahmad,"Revitalisasi Pendidikan Pesantren", Surabaya, 20 Juli, 2009, diakses1Desember2017,revitalisasipendid ikanpesantren.blogspot.co.id/2009/07/bab-iirevitalisasipendidikan. Html

Pakistyaningsih, Arini, dkk. (2014). Menuju Wujud Surabaya Sebagai Kota Literasi, Surabaya: Pelita Hati.

Prawit, M. Yusuf, (2005). Pedoman Penyelenggaraan Perpustakaan Sekolah. Jakarta: Kencana. 
Santoso, Wulandoro, Revitalisasi Dewan Pendidikan, Jumal Ilmu Pendidikan, no.4 juni:2009

Sukmadinata, Nana Syaodih. (2009). Metode Penelitian Pendidikan. Bandung: Remaja Rosdakarya.

Sutarno, NS. (2004). Manajemen Perpustakaan: Suatu Pendekatan Praktik, Jakarta: Samitra Media Utama.

Tantriana, Deasy. (2014). Teori Administrasi, Surabaya: UIN Sunan Ampel Press.

Tim Penyusun Kamus Pusat Bahasa, 2002, Kamus Besar Bahasa Indonesia, Jakarta: Balai Pustaka. 